
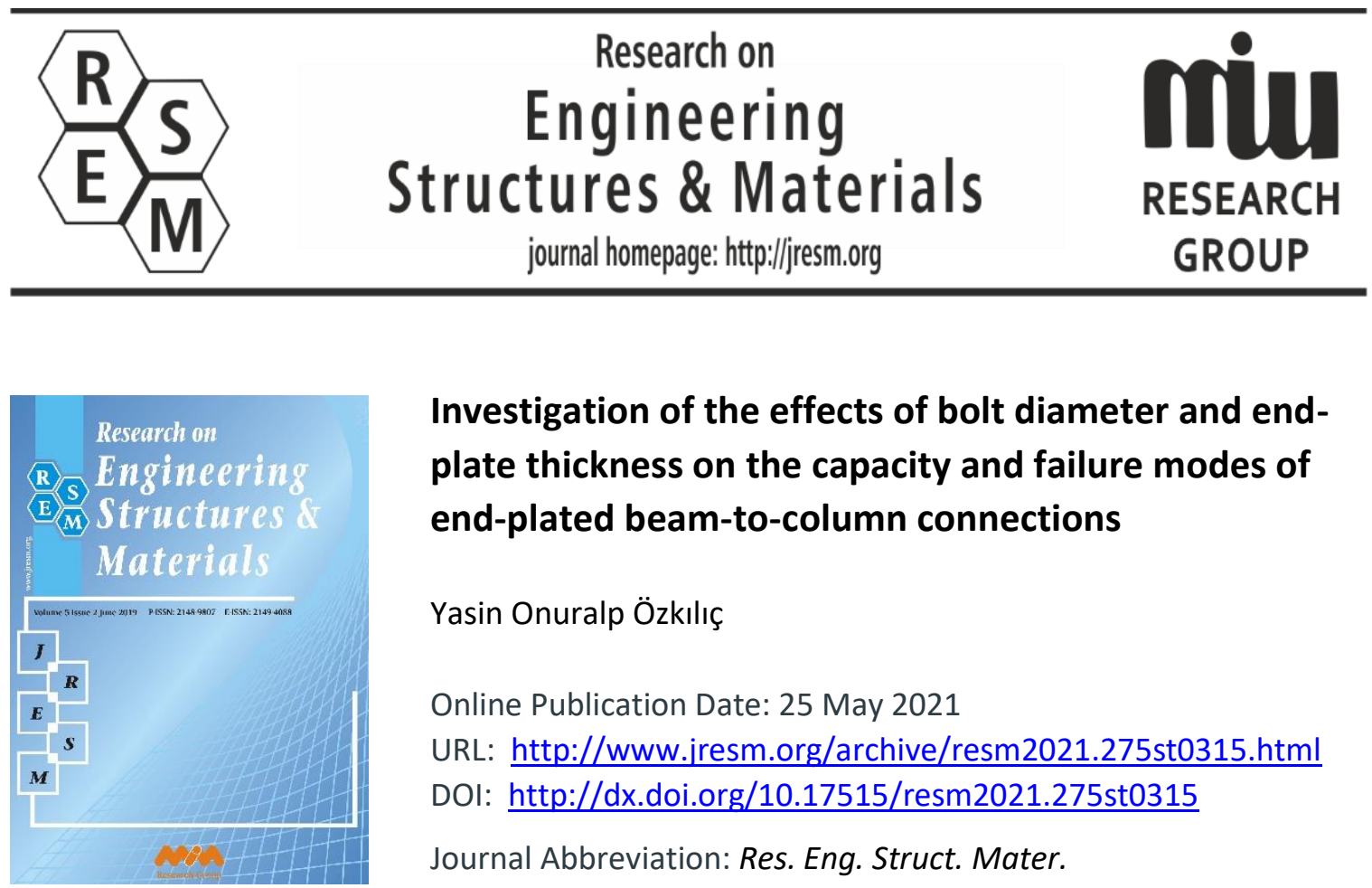

\title{
Investigation of the effects of bolt diameter and end- plate thickness on the capacity and failure modes of end-plated beam-to-column connections
}

Yasin Onuralp Özkılıç

Online Publication Date: 25 May 2021

URL: http://www.jresm.org/archive/resm2021.275st0315.html

DOI: http://dx.doi.org/10.17515/resm2021.275st0315

Journal Abbreviation: Res. Eng. Struct. Mater.

\section{To cite this article}

Özkılıç YO. Investigation of the effects of bolt diameter and end-plate thickness on the capacity and failure modes of end-plated beam-to-column connections. Res. Eng. Struct. Mater., 2021; 7(3) 445-463.

\section{Disclaimer}

All the opinions and statements expressed in the papers are on the responsibility of author(s) and are not to be regarded as those of the journal of Research on Engineering Structures and Materials (RESM) organization or related parties. The publishers make no warranty, explicit or implied, or make any representation with respect to the contents of any article will be complete or accurate or up to date. The accuracy of any instructions, equations, or other information should be independently verified. The publisher and related parties shall not be liable for any loss, actions, claims, proceedings, demand or costs or damages whatsoever or howsoever caused arising directly or indirectly in connection with use of the information given in the journal or related means.

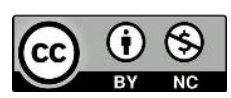

Published articles are freely available to users under the terms of Creative Commons Attribution - NonCommercial 4.0 International Public License, as currently displayed at here (the "CC BY - NC"). 


\title{
Research on Engineering Structures \& Materials \\ journal homepage: http://jresm.org
}

Research Article

\section{Investigation of the effects of bolt diameter and end-plate thickness on the capacity and failure modes of end-plated beam- to-column connections}

\author{
Yasin Onuralp Özkılıç
}

Department of Civil Engineering, Necmettin Erbakan University, Konya, Turkey.

\begin{tabular}{ll} 
Article Info & Abstract \\
\hline $\begin{array}{l}\text { Article history: } \\
\text { Received 15 Mar 2021 }\end{array}$ & $\begin{array}{l}\text { End-plated connections are frequently preferred in beam-to-column } \\
\text { connections due to their advantages of high quality and fast assembly. The } \\
\text { Revised 17 Apr 2021 } \\
\text { capacity of the end-plated connections depends on many parameters including } \\
\text { the thickness of end-plate and bolt diameter. A comprehensive numerical } \\
\text { parametric study was conducted in order to investigate the effects of these } \\
\text { parameters on the capacity of the end-plated connections using the finite } \\
\text { Keywords: }\end{array}$ \\
$\begin{array}{l}\text { End-plate; } \\
\text { element tool, ABAQUS. The results of the numerical study were compared with } \\
\text { the prediction of Eurocode provision in terms of the capacity and failure mode. } \\
\text { connections; }\end{array}$ & $\begin{array}{l}\text { The results showed that Eurocode accurately captures the failure modes and } \\
\text { predicts the capacity of the connection except for thin plates with high accuracy. }\end{array}$ \\
Eurocode; Finite & $\begin{array}{l}\text { However, Eurocode provision significantly underestimated the capacity of the } \\
\text { thin-plated extended end-plated connections. }\end{array}$
\end{tabular}

(C) 2021 MIM Research Group. All rights reserved.

\section{Introduction}

The provisions require that seismic resisting structures should provide sufficient ductility in order to prevent catastrophic failure [1-4]. Welded moment connections exhibited insufficient performance at the 1994 Northridge and 1995 Kobe earthquakes, which resulted in brittle failures. This leads to an increase in the demand for end-plated connections. Compared to welded moment connections, the end-plated connections provide prompt, high quality and economical construction. However, many variables including bolt diameter, thickness of end-plate, yield and ultimate strength of end-plate, bolt configuration, bolt grade, stiffening and the dimensions of beam and column affect the resistance of the end-plate connection. Therefore, more attention is required to calculate the capacity of the end-plated connections.

The end-plated connections can be categorized as flush end-plated connections and extended end-plated connections. The extended end-plated connections are utilized as moment connections and divided into two categories depending on the presence of stiffeners: unstiffened and stiffened extended end-plated connections. The unstiffened extended end-plated connection is shown in Fig. 1. 


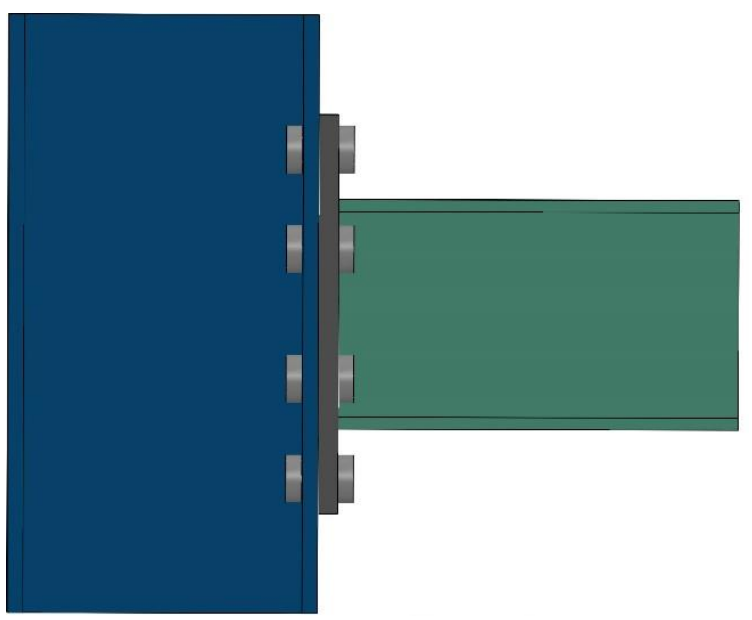

Fig. 1 Extended End-plated Connections

The tension zone of the extended end-plated connections can be idealized by equivalent $\mathrm{T}$ stubs. The behavior of four bolted unstiffened connections can be examined with an unstiffened T-stub (Fig. 2). Eurocode (EC3) [5] utilizes equivalent T-stubs to compute the capacity of the end-plated connections (the details are provided in the following section).
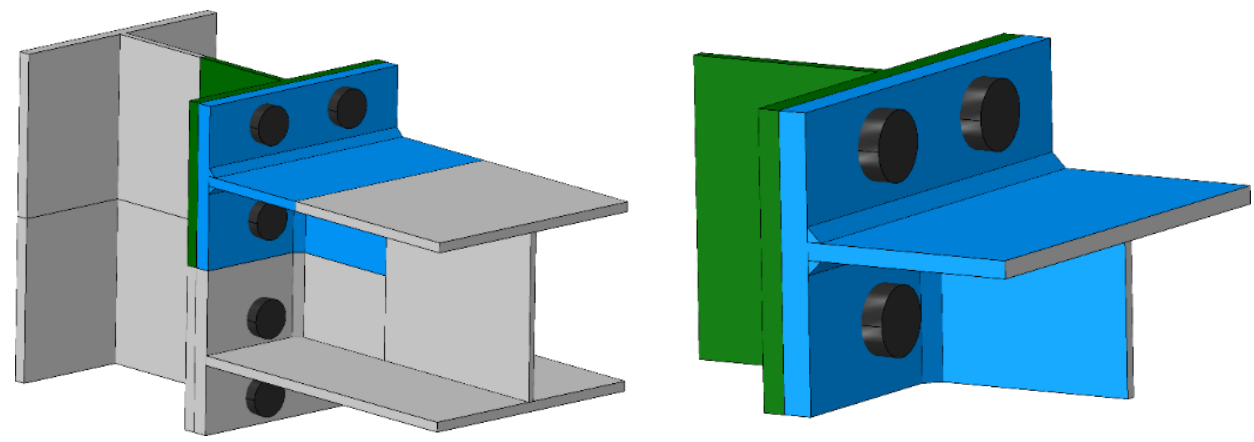

Fig. 2 The idealization of T-stubs

These connections are generally utilized in moment resisting frames as a beam-to-column connection. Moreover, the end-plated connections are also preferred in replaceable fuses in both moment resisting frames [6-9] and eccentrically braced frames [10-13]. The thickness of the end-plate plays a significant role in the weight of a member. Therefore, for replaceable fuses where light members are preferred, the thickness of the end-plate should be correctly designed in order to minimize the weight of the fuse member.

$\mathrm{Ng}$ et al. [14] tested six end-plated connections having different thickness of end-plates. The specimens were monotonically loaded up to failure. The results revealed that Eurocode 3 underestimates the ultimate moment capacity of the end-plated connections for all specimens. Yorgun [15] conducted an experimental study including three specimens under cyclic loading. It was indicated that Eurocode 3 showed conservative results compared to the experimental findings. Abidelah et al. [16] tested four extended endplated connections under monotonic loading. The experimental findings demonstrated that Eurocode 3 gives safe proposals of the moment capacity of the extended end-plated connections. Coelho et al. [17] stated that the prediction of Eurocode 3 gives safe approaches based on the results of eight experimented specimens having extended end- 
plated connections. Zue et al. [18] conducted an experimental program including 13 specimens having extended end-plate connections. It was emphasized that Eurocode 3 underestimated the ultimate capacity by $41-45 \%$.

Özkılıç and Topkaya [19] collected the results of end-plated specimens from literature and compared with the prediction of Eurocode provision. It was reported that the difference between the experimental results and predicted value reached ratios of 1.73 and 3.0 for plastic and ultimate moment capacities, respectively. Apart from the studies of extended end-plated connections, the studies [20-25] conducted for T-stub joints revealed that the Eurocode also underestimates the resistance of T-stub joints.

In this study, the prediction of Eurocode 3 for unstiffened end-plated connections was evaluated using numerical analysis. A parametric study was conducted to further investigate the conservative prediction of Eurocode 3. Furthermore, failure modes obtained from numerical analysis are compared with the prediction of Eurocode 3.

\section{The European Provisions}

EN1998-1 [26] provides the design procedure of beam-to-column connections in moment resisting frames while EN1993-1-8 [5] provides the required calculations for designing joints. The component methods were adapted by Eurocode provisions to calculate the resistance of the bolted end-plated connections. In this method, the strengths of individual failure modes are computed.

Three different failure modes including complete flange yielding, flange yielding with bolt failure and bolt failure $[27,28]$ can develop on the T-stubs where the tension of the endplated connection can be idealized. The first failure mode is a ductile behavior that resulted due to significantly large plastic deformation of the T-stub flange. This is achieved by forming plastic hinges in the flange of the T-stub. Unlike the first failure mode, limited ductility occurs in the third failure mode and is associated with failure of the bolts in tension. On the other hand, the second failure mode is combined both bolt failure and flange yielding. These failure modes are illustrated in Fig. 3. The resistance of the T-stub is taken as the weakest of these failure modes, which exhibits the lowest capacity.
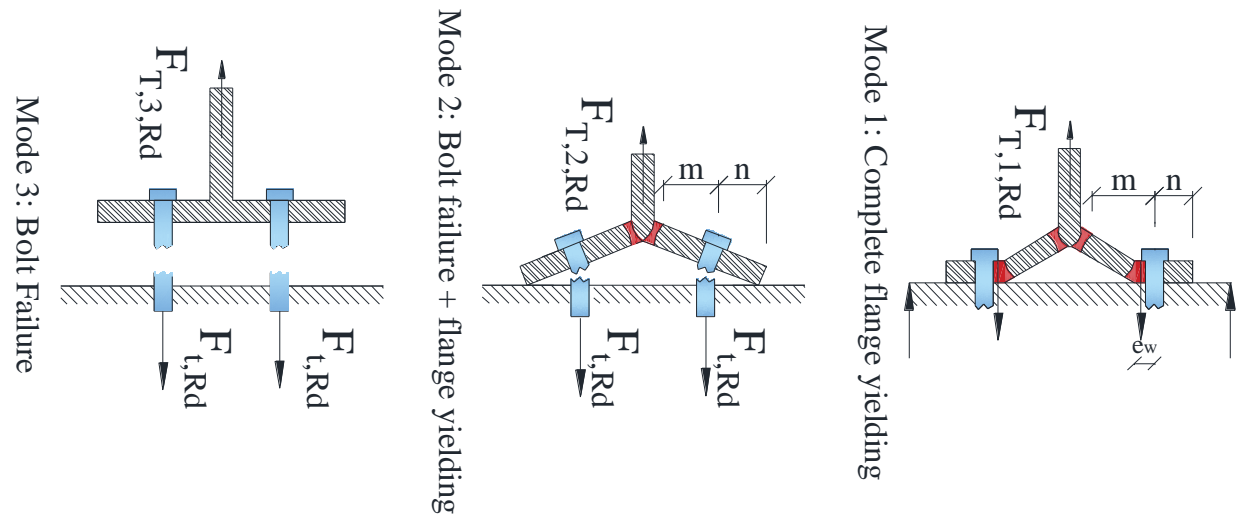

Fig. 3 Failure Modes of T-stub

The resistance of Failure Mode 1 can be computed by two different methods (Method 1 and Method 2). Method 1 assumes that the bolt forces concentrate on the centreline of the bolt. On the other hand, the effects of bolt/washer size are included in Method 2 which assumes that bolt forces are distributed under the washer/nut. In other words, Method 2 considers that the distance between two plastic hinges, which pass over the toe of the fillet 
and next to the edges of the bolt row, are less than m. Therefore, it is expected that Method 2 results in a higher capacity than that of Method 1 . These methods can be computed from the following equations [5].

Method 1:

$$
\begin{aligned}
& F_{T, 1 R d}=\frac{4 M_{p, 1 R d}}{m} \\
& n=\min \left(e_{x} ; 1.25 m\right) \\
& M_{p, 1 R d}=0.25 l_{e f f, 1} t_{p}^{2} F_{y p}
\end{aligned}
$$

Method 2:

$$
F_{T, 1 R d}=\frac{\left(32 n-2 d_{w}\right) M_{p, 1 R d}}{8 m n-d_{w}(m+n)}
$$

where $d_{w}$ is diameter of washer, bolt head or nut, $t_{p}$ is thickness of end-plate, $e_{x}$ is the vertical edge distance for outside holes, $m$ is the distance from the center of a bolt to fillet weld of flange. $l_{e f f, 1}$ is minimum of $l_{\text {eff,cp }}$ and $l_{\text {eff,nc. }} l_{\text {eff,cp }}$ is the length of the circular yield line pattern and leff,nc is the length of the non-circular yield line pattern. Multiple yield line mechanisms depending on the geometry are available in P398 [29]. Individual or group yielding may occur relying on the gage distance $(w)$. Fig. 4 illustrates the variables used in the calculation of end-plated connection capacity by Eurocode 3. Yield line mechanisms and their calculations for unstiffened end-plated connections are demonstrated in Figs. 5 and 6. Fig. 5(a) illustrates the defined parameters used in the calculations. Figs. 5(b-d) and Fig. 5(e-g) show circular and non-circular yield patterns for outer side of bolt (bolt row 1), respectively. On the other hand, Fig. 6 demonstrates the yield lines for inner bolt row (bolt row 2).

For Failure Mode 2:

$$
\begin{aligned}
& F_{T, 2 R d}=\frac{2 M_{p, 1 R d}+n 2 F_{T, R d}}{(m+n)} \\
& F_{T, R d}=\frac{k_{2} f_{u b} A_{s}}{\gamma_{M 2}}
\end{aligned}
$$

For Failure Mode 3:

$$
\begin{aligned}
& F_{T, 3 R d}=2 F_{t, R d} \\
& M_{p, 2 R d}=0.25 l_{e f f, 2} t_{p}^{2} F_{y p}
\end{aligned}
$$

where $A_{s}$ is tensile stress are of a bolt, $f_{u b}$ is the nominal ultimate strength of bolt, leff, 2 is minimum of $l_{\text {eff,nc. }}$. The minimum of these three failure modes is taken as the resistance of bolt row which should be calculated separately for each bolt row.

Resistance of bolt row 1 (bolt row above the top flange):

$$
F_{t, 1 R d}=\min \left(F_{T, R 1 d} ; F_{T, R 2 d} ; F_{T, R 3 d}\right)
$$

Resistance of bolt row 2 (bolt row below the top flange): 


$$
F_{t, 2 R d}=\min \left(F_{T, R 1 d} ; F_{T, R 2 d} ; F_{T, R 3 d}\right)
$$

After calculating the design resistance of bolt rows, the design moment is calculated as follows:

$$
M_{j, R d}=h_{1} F_{t, R 1 d}+h_{2} F_{t, R 2 d}
$$

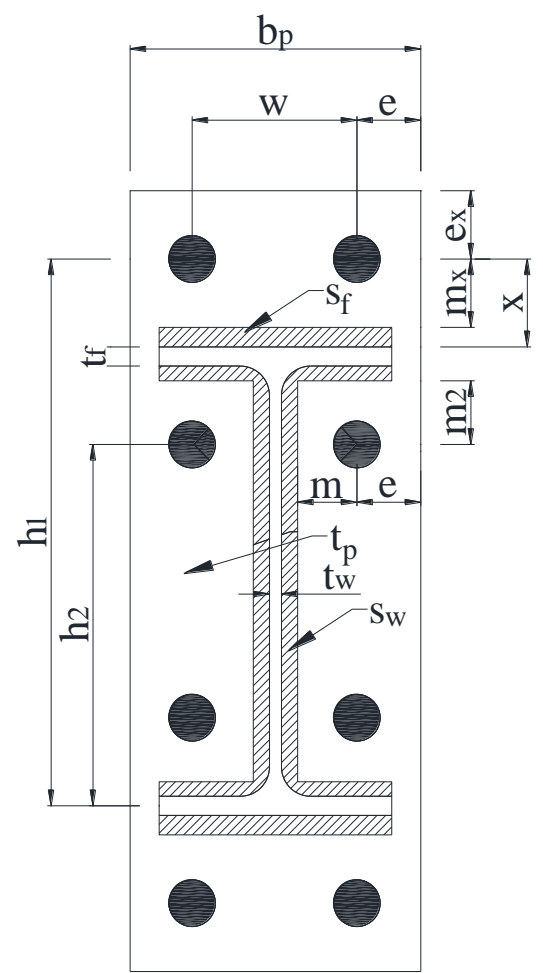

Fig. 4 Parameters used in Eurocode 3 


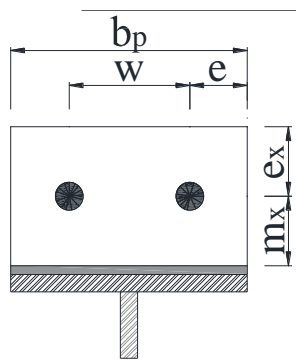

a) Parameters

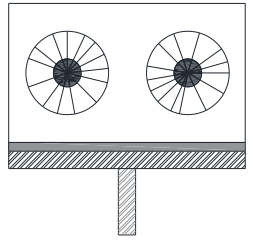

b) Circular yielding $1_{\text {eff,cp }}=2 \pi m_{x}$

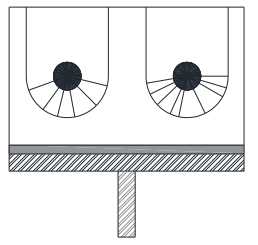

c) Individual end yielding $1_{\text {eff,cp }}=\pi m_{x}+2 e_{x}$

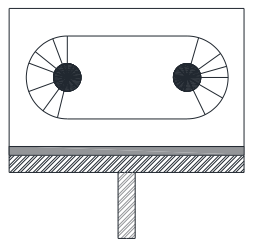

d) Circular group yielding $1_{\text {eff,cp }}=\pi m_{x}+\mathrm{w}$

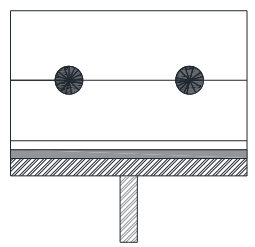

e) Double curvature

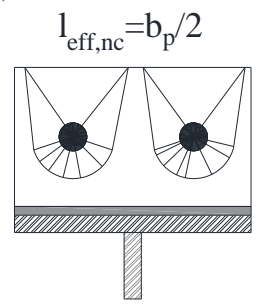

f) Individual end yielding $1_{\text {eff,nc }}=4 m_{x}+1.25 e_{x}$

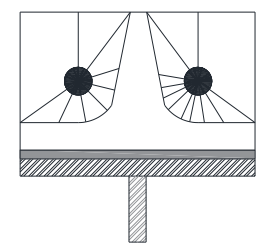

g) Corner yielding $1_{\text {eff }, n c}=2 m_{x}+0.625 e_{x}+e$

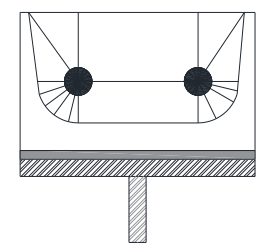

h) Group end yielding

$1_{\text {eff,nc }}=2 m_{x}+0.625 e_{x}+w / 2$

Fig. 5 Yield lines for outer bolt row 


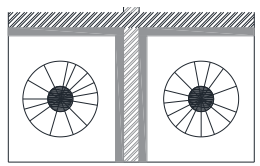

a) Circular yielding $1_{\text {eff,cp }}=2 \pi \mathrm{m}$

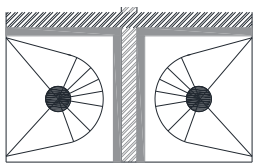

b) Side yielding near beam or a stiffener $1_{\text {eff,nc }}=\alpha \mathrm{m}$

Fig. 6 Yield lines for inner bolt row

\section{Numerical Study}

A comprehensive numerical study was performed in order to investigate the effects of bolt diameter and end-plate thickness on the resistance and failure modes of extended endplated connections. The numerical analyses were carried out using the finite element tool, ABAQUS. Three-dimensional elements were utilized to construct the models. The column was not modeled explicitly. Instead, a rigid flange was defined to simulate the connection between the column and beam.

Solid elements were utilized for all members. The element type of C3D8R was selected for all components. Fine mesh size was selected for the bolts, end-plate and welds whereas coarse mesh size was utilized for the beam. The selected mesh configuration is illustrated in Figure 7. In order to accurately simulate the bending behavior of the member, the thickness of members should be divided into at least four elements [6]. Therefore, 4 elements through the thickness of the end-plate and through the flanges and web of the beam were utilized.

Encastre boundary conditions were applied to the bottom of the rigid flange. The finite sliding surface to surface interaction was defined between end-plate and rigid flange, between bolts and rigid flange and between bolts and end-plate. The penalty method with a friction coefficient of 0.3 was applied for the tangential behavior. The bolts were pretensioned using Bolt-Load option. Both geometrical and material nonlinearities were implemented in the models. The loading was applied at the end of the beam. The beams were loaded up to $0.04 \mathrm{rad}$ rotation since minumum rotation capacity of 0.035 rad rotation is required by Eurocode 8 .

The welds were explicitly included in the models to simulate the behavior of the connection accurately. P398 [29] offers a simple solution for the thickness of the weld. 8 $\mathrm{mm}$ leg fillet welds for the entire web were utilized based on the recommendation of P398. On the other hand, the welds between the flange and end plate were designed as full strength. The strength of the weld was taken equal to the resistance of the tension flange. Based on the calculations, $10 \mathrm{~mm}$ leg fillet welds were utilized for both the tension and compression flanges. 

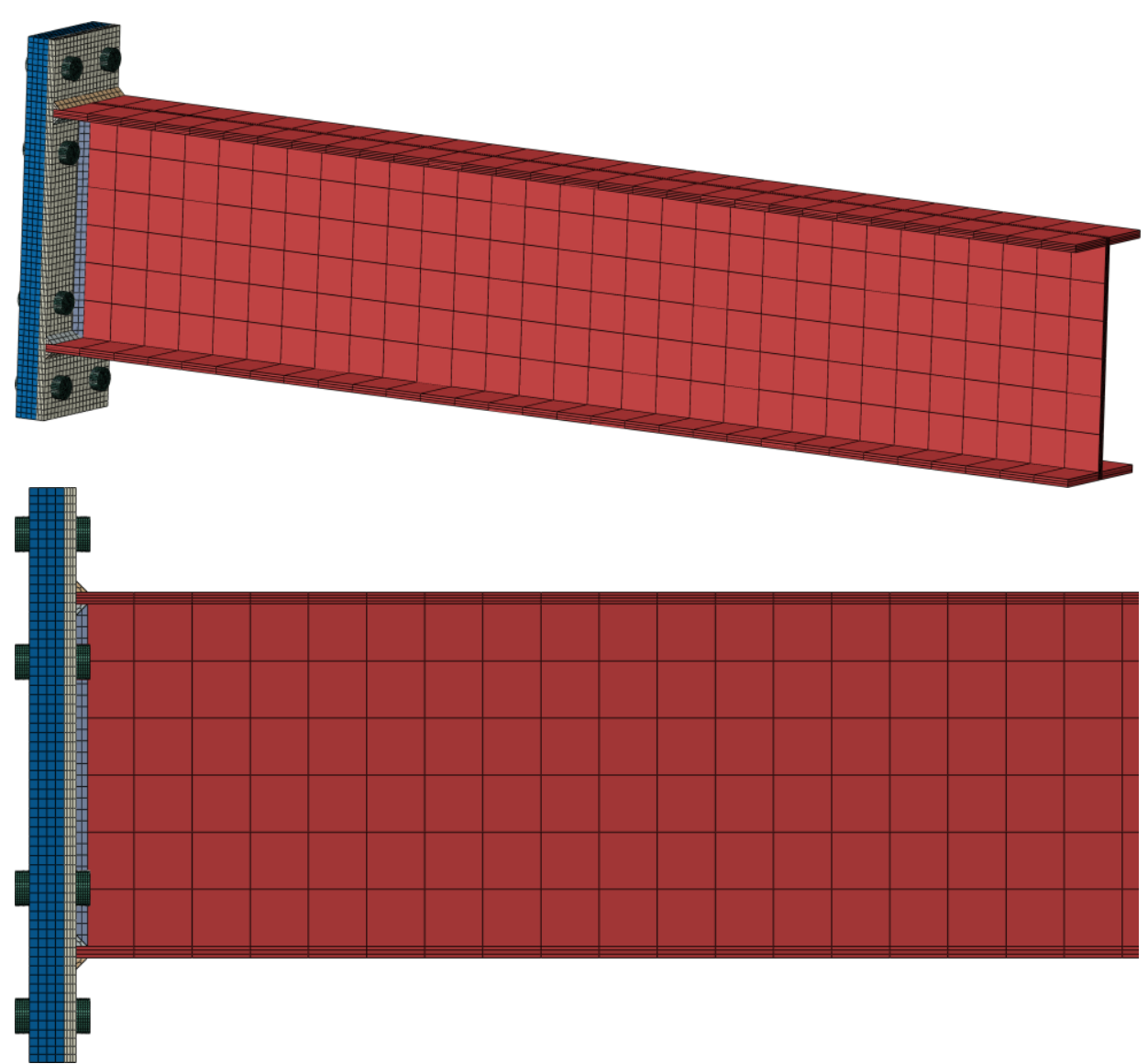

Fig. 7 Selected mesh configuration

The rigid flange was modeled as elastic. For material models of the end-plate and beam, the multilinear stress-strain curve developed by Yun and Gardner [30] was utilized. S275 and S420 were selected for material properties of the end-plate and beam, respectively. Young's modulus and Poisson's ratio were selected as $200 \mathrm{GPa}$ and 0.3 , respectively.

The assumptions utilized in the numerical study were verified using the study conducted by Qiang et al. [31]. Qiang et al. [31] monotonically tested specimens having extended endplated connections. The beam utilized in the verification had the dimensions of 300, 180, 10 and $12 \mathrm{~mm}$ for depth, width, web thickness and flange thickness, respectively. A diameter of $27 \mathrm{~mm}$ and thickness of $12 \mathrm{~mm}$ was utilized for the bolts and end-plate. Fig. 8 compares the results of the numerical model and experimental findings. A difference of $5 \%$ was observed at the ultimate load. Moreover, the numerical model is slightly stiffer than the experimental results. This can be attributed to the rigid flange. It can be said that the numerical models are capable of predicting the behavior of the extended end-plate connections. 


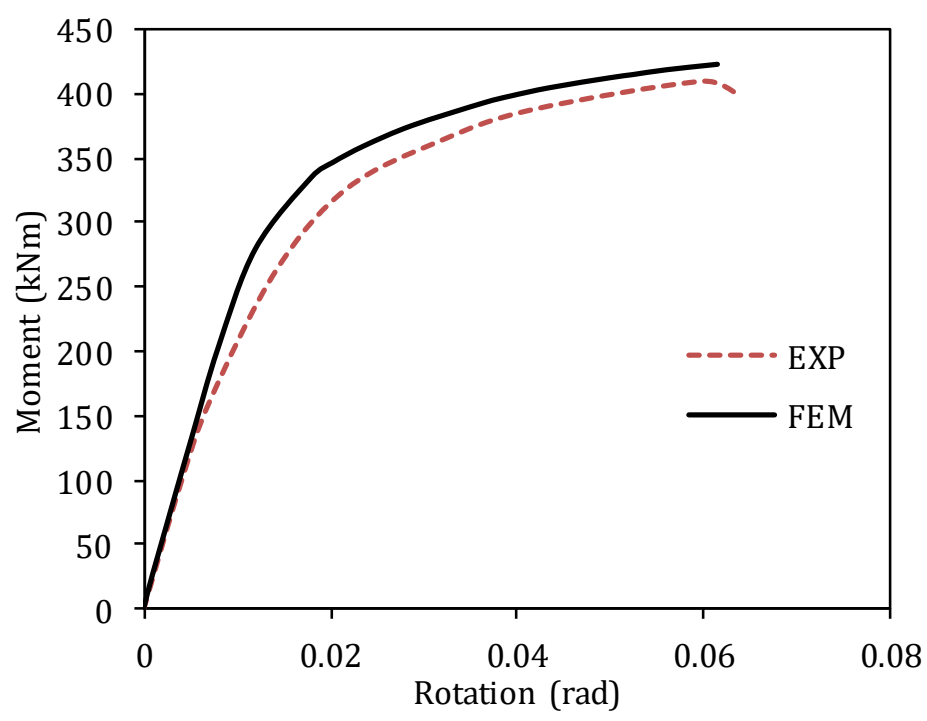

Fig. 8 The verification model

For the parametric study, the beam was selected for a typical beam section of European profiles which is approximately dimensions of IPE300 section since Eurocode provision is evaluated. The dimensions of the beam and end-plate are given in Table 1 and shown in Fig. 9. The selected parameters are shown in Table 2. Bolt diameters of $16 \mathrm{~mm}$ (M16), 20 $\mathrm{mm}$ (M20), $24 \mathrm{~mm}$ (M24), $27 \mathrm{~mm}$ (M27) and $30 \mathrm{~mm}$ (M30) and end-plate thickness ( $\left.t_{p}\right)$ of $10 \mathrm{~mm}, 15 \mathrm{~mm}, 20 \mathrm{~mm}, 25 \mathrm{~mm}$ and $30 \mathrm{~mm}$ were selected as variables.

Table 1 . The dimensions of the end-plate and beam

\begin{tabular}{cc}
\hline Variables & Value $(\mathrm{mm})$ \\
\hline $\mathrm{b}_{\mathrm{f}}$ & 150 \\
$\mathrm{~b}_{\mathrm{p}}$ & 150 \\
$\mathrm{w}$ & 90 \\
$\mathrm{~m}_{2}$ & 40 \\
$\mathrm{~m}_{\mathrm{x}}$ & 40 \\
$\mathrm{e}_{\mathrm{x}}$ & 40 \\
$\mathrm{~S}_{\mathrm{w}}$ & 8 \\
$\mathrm{t}_{\mathrm{w}}$ & 8 \\
$\mathrm{~S}_{\mathrm{f}}$ & 10 \\
$\mathrm{t}_{\mathrm{f}}$ & 10 \\
$\mathrm{~h}_{1}$ & 360 \\
$\mathrm{~h}_{2}$ & 250 \\
\hline
\end{tabular}




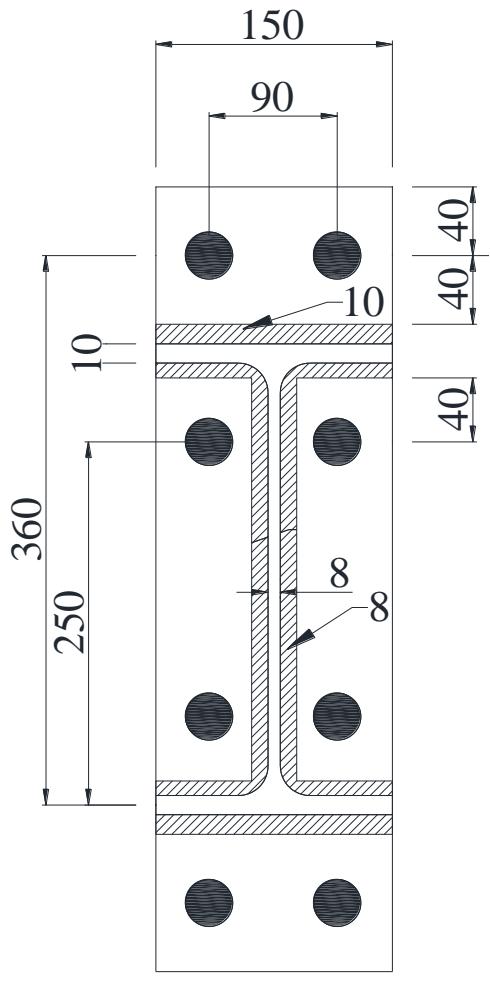

Fig. 9 The selected configuration

Table 2. The selected variables

\begin{tabular}{cccccc}
\hline Variables & Values \\
\hline Bolt Diameter (mm) & 16 & 20 & 24 & 27 & 30 \\
Thickness of End-plate (mm) & 10 & 15 & 20 & 25 & 30 \\
\hline
\end{tabular}

\section{Results and Discussion}

The results of the parametric study are given in Table 3 and moment-rotation curves are given in Figs. 10 and 11. Two different capacities of the end-plated connections are reported in Table 3. $M_{u}$ represents the maximum moment observed in the models up to $0.04 \mathrm{rad}$ rotation. On the other hand, $M_{j, R d}$ is calculated from the intersection moment that passes from the initial and post stiffness. The moment design capacity $\left(M_{j, R d}\right)$ is also called plastic resistance $[21,24,32]$. It should also be noted that the plastic bending capacity of the beam is $283 \mathrm{kN}$. 
Table 3. The results of parametric study

\begin{tabular}{|c|c|c|c|c|c|c|c|}
\hline Models & $\mathrm{M}_{\mathrm{EC}, 1}$ & $\mathrm{M}_{\mathrm{EC}, 2}$ & $\mathrm{M}_{\mathrm{j}, \mathrm{Rd}}$ & $\mathrm{M}_{\mathrm{u}}$ & $\begin{array}{c}\mathrm{M}_{\mathrm{u}} \\
/ \mathrm{M}_{\mathrm{j}, \mathrm{Rd}}\end{array}$ & $\begin{array}{l}\mathrm{M}_{\mathrm{EC}, 1} \\
/ \mathrm{M}_{\mathrm{j}, \mathrm{Rd}}\end{array}$ & $\begin{array}{l}\mathrm{M}_{\mathrm{EC}, 2} \\
/ \mathrm{M}_{\mathrm{j}, \mathrm{Rd}}\end{array}$ \\
\hline M16-tp=10mm & 54 & 65 & 87 & 142 & 1.6 & 0.62 & 0.75 \\
\hline M16-tp=15mm & 98 & 105 & 147 & 182 & 1.3 & 0.67 & 0.71 \\
\hline M16-tp=20mm & 143 & 143 & 153 & 200 & 1.3 & 0.93 & 0.93 \\
\hline M16-tp $=25 \mathrm{~mm}$ & 156 & 156 & 176 & 222 & 1.3 & 0.89 & 0.89 \\
\hline M16-tp $=30 \mathrm{~mm}$ & 169 & 169 & 195 & 237 & 1.2 & 0.86 & 0.86 \\
\hline $\mathrm{M} 20-\mathrm{tp}=10 \mathrm{~mm}$ & 54 & 73 & 114 & 180 & 1.6 & 0.47 & 0.64 \\
\hline $\mathrm{M} 20-\mathrm{tp}=15 \mathrm{~mm}$ & 119 & 129 & 186 & 237 & 1.3 & 0.64 & 0.70 \\
\hline $\mathrm{M} 20-\mathrm{tp}=20 \mathrm{~mm}$ & 167 & 186 & 223 & 270 & 1.2 & 0.75 & 0.83 \\
\hline $\mathrm{M} 20-\mathrm{tp}=25 \mathrm{~mm}$ & 224 & 224 & 239 & 284 & 1.2 & 0.94 & 0.94 \\
\hline $\mathrm{M} 20-\mathrm{tp}=30 \mathrm{~mm}$ & 241 & 241 & 256 & 297 & 1.2 & 0.94 & 0.94 \\
\hline $\mathrm{M} 24-\mathrm{tp}=10 \mathrm{~mm}$ & 54 & 73 & 128 & 210 & 1.6 & 0.42 & 0.57 \\
\hline M24-tp=15mm & 122 & 155 & 195 & 271 & 1.4 & 0.62 & 0.79 \\
\hline $\mathrm{M} 24-\mathrm{tp}=20 \mathrm{~mm}$ & 192 & 211 & 283 & 301 & 1.1 & 0.68 & 0.75 \\
\hline $\mathrm{M} 24-\mathrm{tp}=25 \mathrm{~mm}$ & 253 & 283 & 283 & 314 & 1.1 & 0.90 & 1.00 \\
\hline $\mathrm{M} 24-\mathrm{tp}=30 \mathrm{~mm}$ & 322 & 322 & 283 & 314 & 1.1 & 1.14 & 1.14 \\
\hline $\mathrm{M} 27-\mathrm{tp}=10 \mathrm{~mm}$ & 54 & 77 & 153 & 231 & 1.5 & 0.35 & 0.50 \\
\hline $\mathrm{M} 27-\mathrm{tp}=15 \mathrm{~mm}$ & 122 & 173 & 221 & 295 & 1.3 & 0.55 & 0.78 \\
\hline $\mathrm{M} 27-\mathrm{tp}=20 \mathrm{~mm}$ & 213 & 237 & 283 & 310 & 1.1 & 0.75 & 0.84 \\
\hline $\mathrm{M} 27-\mathrm{tp}=25 \mathrm{~mm}$ & 275 & 311 & 283 & 314 & 1.1 & 0.97 & 1.10 \\
\hline $\mathrm{M} 27-\mathrm{tp}=30 \mathrm{~mm}$ & 351 & 373 & 283 & 314 & 1.1 & 1.24 & 1.32 \\
\hline M30-tp=10mm & 54 & 82 & 164 & 250 & 1.5 & 0.33 & 0.50 \\
\hline M30-tp=15mm & 122 & 183 & 283 & 314 & 1.1 & 0.43 & 0.65 \\
\hline M30-tp $=20 \mathrm{~mm}$ & 216 & 265 & 283 & 314 & 1.1 & 0.76 & 0.94 \\
\hline M30-tp=25mm & 300 & 342 & 283 & 314 & 1.1 & 1.06 & 1.21 \\
\hline M30-tp=30mm & 375 & 431 & 283 & 314 & 1.1 & 1.32 & 1.52 \\
\hline
\end{tabular}

It is seen in Table 3 that the ratio of $M_{u} / M_{j, R d}$ varies between 1.1 and 1.6. As the thickness of the end-plate decreases, the ratio of $M_{u} / M_{j, R d}$ increases. On the other hand, as the bolt diameter increase, the ratio of $M_{u} / M_{j, R d}$ decreases.

Increasing thickness of the end-plate resulted in an increase in both plastic and ultimate moment capacity. However, when the bending moment capacity of the beam is lower than that of the connection, increasing the thickness of the end-plate has no influence on the capacity. The same results can be drawn for the diameter of the bolts.

The prediction of Eurocode using Method $2\left(M_{E C, 2}\right)$ is averagely $17 \%$ higher than that of Method $1\left(M_{E C, 1}\right)$. This ratio reached a maximum of $51 \%$ when a thin end-plate is utilized with large size of bolt. The ratio of $M_{E C, 2} / M_{E C, 1}$ is high when Mode 1 is governing failure mode. When governing failure mode is Mode 3, the prediction of Methods 1 and 2 is equal. 
The ratio of moment prediction by Eurocode to the plastic moment capacity is averagely 0.77 and 0.87 for Methods 1 and 2, respectively. The accuracy of the Eurocode prediction is high when governing failure mode is Mode 2 and 3 . However, the accuracy is relatively low when governing failure mode is Mode 1 . The accuracy decreases as the bolt diameter increases. On the other hand, the accuracy increases as the end-plate increases.

It is observed in Fig. 10 that as the diameter of the bolt increases, the initial stiffness of the connection increases. The increase in the stiffness is more pronounced in the relatively thin plates. When the connection exceeds the bending capacity of the beam, the diameter of the bolts has a very slight influence on the initial stiffness of the connection.

It is observed in Fig. 11 that as the thickness of the end-plate increases, the initial stiffness of the connection increases. The increase in the stiffness is more pronounced in the relatively small bolts. When the connection exceeds the bending capacity of the beam, the thickness of the end-plate has a very slight influence on the initial stiffness of the connection.

Table 4 demonstrates the failure modes observed in the numerical models and the prediction of Eurocode. The failure modes defined in Eurocode are shown in Fig. 3. The corresponding failure modes captured by the numerical model are demonstrated in Fig. 12. The failure of the beam is also shown in Figure 13. It can be said that the failure modes predicted by Eurocode are quite accurate when it is compared with the results of numerical models. 

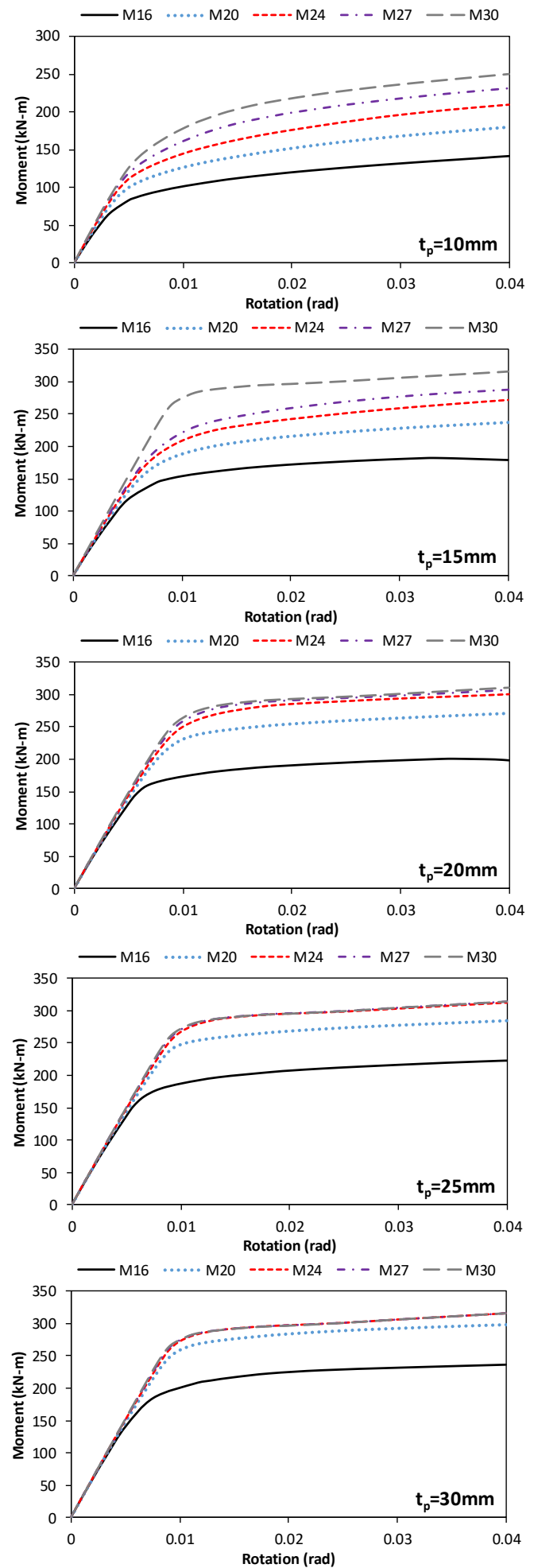

Fig. 10 The results of the parametric study of different bolt diameter 

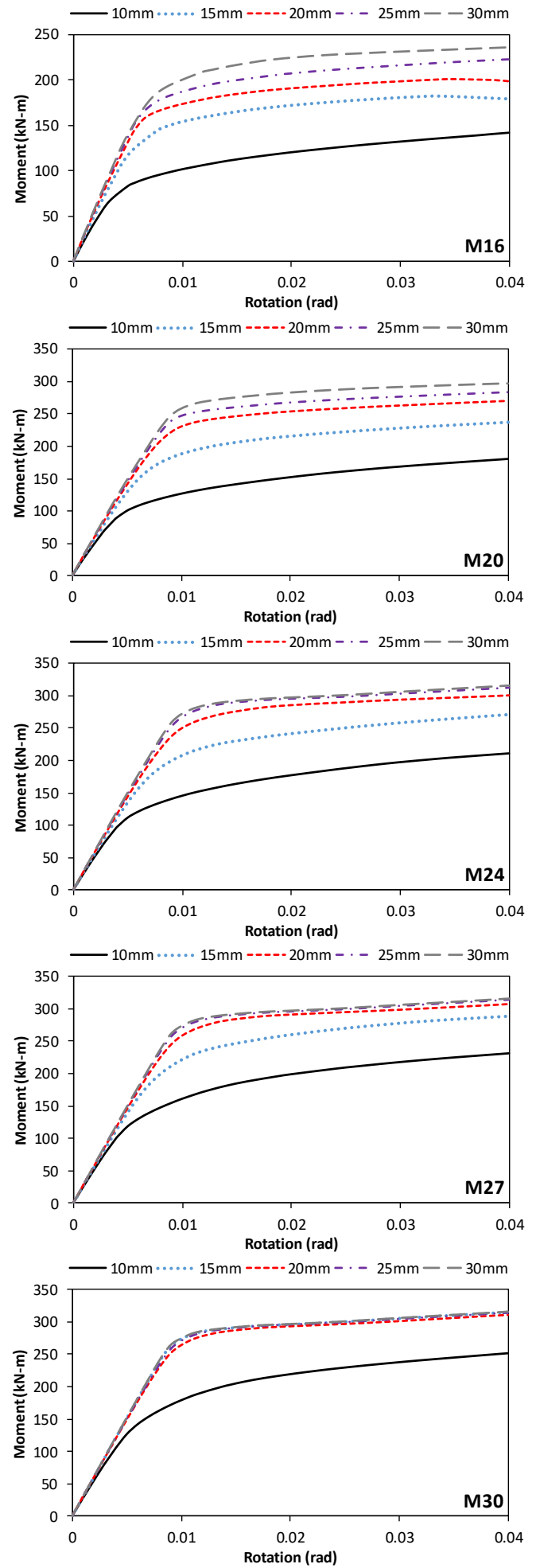

Fig. 11 The results of the parametric study of different end-plate thickness 


\section{Failure Mode 1}

\section{Failure Mode 2}

\section{$\underline{\text { Failure Mode } 3}$}

Fig. 12 Failure modes of end-plate 


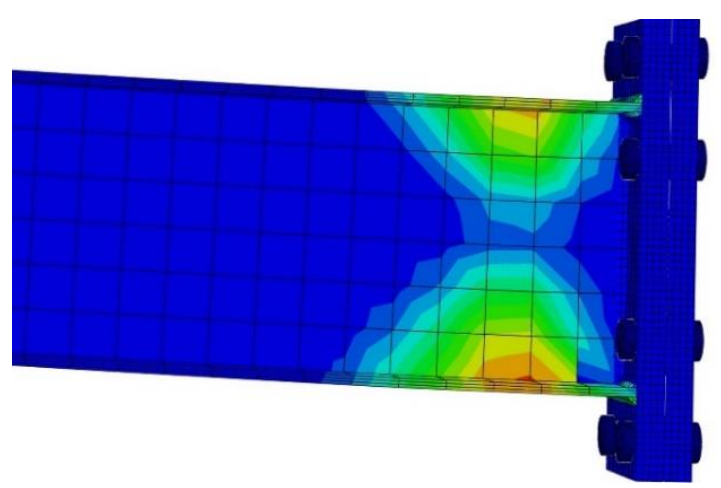

Fig. 13 Failure of the beam

Table 4. The results of parametric study

\begin{tabular}{|c|c|c|c|c|}
\hline \multirow{2}{*}{ Models } & \multicolumn{2}{|c|}{ Finite Element } & \multicolumn{2}{|c|}{ Eurocode 3} \\
\hline & Bolt Row 1 & Bolt Row 2 & Bolt Row 1 & Bolt Row 2 \\
\hline $\mathrm{M} 16-\mathrm{tp}=10 \mathrm{~mm}$ & Mode 1 & Mode 1 & Mode 1 & Mode 1 \\
\hline M16-tp=15mm & Mode 1 & Mode 1 & Mode 1 & Mode 2 \\
\hline $\mathrm{M} 16-\mathrm{tp}=20 \mathrm{~mm}$ & Mode 2 & Mode 2 & Mode 2 & Mode 3 \\
\hline M16-tp $=25 \mathrm{~mm}$ & Mode 3 & Mode 3 & Mode 2 & Mode 3 \\
\hline $\mathrm{M} 16-\mathrm{tp}=30 \mathrm{~mm}$ & Mode 3 & Mode 3 & Mode 2 & Mode 3 \\
\hline $\mathrm{M} 20-\mathrm{tp}=10 \mathrm{~mm}$ & Mode 1 & Mode 1 & Mode 1 & Mode 1 \\
\hline $\mathrm{M} 20-\mathrm{tp}=15 \mathrm{~mm}$ & Mode 1 & Mode 1 & Mode 1 & Mode 2 \\
\hline $\mathrm{M} 20-\mathrm{tp}=20 \mathrm{~mm}$ & Mode 2 & Mode 2 & Mode 1 & Mode 2 \\
\hline $\mathrm{M} 20-\mathrm{tp}=25 \mathrm{~mm}$ & Mode 2 & Mode 2 & Mode 2 & Mode 3 \\
\hline $\mathrm{M} 20-\mathrm{tp}=30 \mathrm{~mm}$ & Mode 2 & Mode 2 & Mode 2 & Mode 3 \\
\hline $\mathrm{M} 24-\mathrm{tp}=10 \mathrm{~mm}$ & Mode 1 & Mode 1 & Mode 1 & Mode 1 \\
\hline $\mathrm{M} 24-\mathrm{tp}=15 \mathrm{~mm}$ & Mode 1 & Mode 1 & Mode 1 & Mode 1 \\
\hline $\mathrm{M} 24-\mathrm{tp}=20 \mathrm{~mm}$ & Mode 1 & Mode 1 & Mode 1 & Mode 2 \\
\hline $\mathrm{M} 24-\mathrm{tp}=25 \mathrm{~mm}$ & Beam Failure & Beam Failure & Beam Failure & Beam Failure \\
\hline $\mathrm{M} 24-\mathrm{tp}=30 \mathrm{~mm}$ & Beam Failure & Beam Failure & Beam Failure & Beam Failure \\
\hline $\mathrm{M} 27-\mathrm{tp}=10 \mathrm{~mm}$ & Mode 1 & Mode 1 & Mode 1 & Mode 1 \\
\hline $\mathrm{M} 27-\mathrm{tp}=15 \mathrm{~mm}$ & Mode 1 & Mode 1 & Mode 1 & Mode 1 \\
\hline $\mathrm{M} 27-\mathrm{tp}=20 \mathrm{~mm}$ & Beam Failure & Beam Failure & Mode 1 & Mode 2 \\
\hline $\mathrm{M} 27-\mathrm{tp}=25 \mathrm{~mm}$ & Beam Failure & Beam Failure & Beam Failure & Beam Failure \\
\hline $\mathrm{M} 27-\mathrm{tp}=30 \mathrm{~mm}$ & Beam Failure & Beam Failure & Beam Failure & Beam Failure \\
\hline $\mathrm{M} 30-\mathrm{tp}=10 \mathrm{~mm}$ & Mode 1 & Mode 1 & Mode 1 & Mode 1 \\
\hline $\mathrm{M} 30-\mathrm{tp}=15 \mathrm{~mm}$ & Beam Failure & Beam Failure & Mode 1 & Mode 1 \\
\hline $\mathrm{M} 30-\mathrm{tp}=20 \mathrm{~mm}$ & Beam Failure & Beam Failure & Mode 1 & Mode 1 \\
\hline M30-tp $=25 \mathrm{~mm}$ & Beam Failure & Beam Failure & Beam Failure & Beam Failure \\
\hline $\mathrm{M} 30-\mathrm{tp}=30 \mathrm{~mm}$ & Beam Failure & Beam Failure & Beam Failure & Beam Failure \\
\hline
\end{tabular}




\section{Conclusion}

A comprehensive numerical study was conducted to examine the effects of the bolt diameter and end-plate thickness on the behavior of the end-plated connections using the finite element tool, ABAQUS. Firstly, the developed numerical model is verified with an experimental study. Later, an extensive parametric study is carried out. The loaddisplacement curves, failure modes, plastic and ultimate moment capacities are presented. Moreover, the results were compared with the prediction of Eurocode in terms of the resistance and failure modes. The following conclusions can be drawn from this study:

- The ultimate capacity of the end-plated connection is significantly higher than the plastic capacity of the connection. The reason for this can be attributed to strain hardening [19]. The difference is more pronounced in thin plates with large bolts.

- Method 1 predicts moment capacity averagely $17 \%$ higher accuracy than Method 2 does.

- The accuracy of Eurocode prediction is higher when the governing failure mode is Mode 2 or Mode 3. The accuracy of Eurocode prediction is low when the governing failure mode is Mode 1.

- Eurocode significantly underestimates the capacity of the end-plated connection when a relatively thin end-plate is utilized. The accuracy decreases as end-plate thickness decreases or the bolt diameter increases.

- The initial stiffness of the end-plated connection increases as the bolt diameter or end-thickness increases.

- Eurocode is highly able to predict the failure modes of the end-plated connection.

In future studies, the reason for the conservative prediction of Eurocode for thin endplated connections should be investigated. The capacity of the end-plated connection significantly depends on the yield line patterns [33]. The reason for this underestimation may be attributed to the distance between the yield lines, which is declared by Özkılıç and Topkaya [19]. Therefore, an extensive experimental program should be conducted to investigate the effects of the parameters including thickness of end-plate, width of endplate, gage distance, bolt diameter, weld thickness, the distance between the bolt row and the flange and edge distance on the capacity of the end-plated connections.

\section{References}

[1] Inel M, Ozmen HB, Bilgin H. Re-evaluation of building damage during recent earthquakes in Turkey. Engineering Structures, 2008;30:412-27. https://doi.org/10.1016/j.engstruct.2007.04.012

[2] Işıı E, Işık MF, Bülbül MA. Web based evaluation of earthquake damages for reinforcedconcrete buildings. Earthquakes and Structures, 2017;13:423-32.

[3] Kalman Šipoš T, Hadzima-Nyarko M. Seismic risk of Croatian cities based on building's vulnerability. Tehnički vjesnik, 2018;25:1088-94. https://doi.org/10.17559/TV20170708190145

[4] Hakan Arslan M. Application of ANN to evaluate effective parameters affecting failure load and displacement of RC buildings. Natural Hazards and Earth System Sciences, 2009;9:967-77. https://doi.org/10.5194/nhess-9-967-2009

[5] EN 1993-1-8: Design of steel structures, Part 1.8: Design of joints. 2005.

[6] Özkılıç YO. A new replaceable fuse for moment resisting frames: Replaceable bolted reduced beam section connections. Steel and Composite Structures, 2020;35(3):353-70. http://dx.doi.org/10.12989/scs.2020.35.3.353 
[7] Nikoukalam MT, Dolatshahi KM. Development of structural shear fuse in moment resisting frames. Journal of Constructional Steel Research, 2015;114:349-61. https://doi.org/10.1016/j.jcsr.2015.08.008

[8] Moradi Garoosi A, TahamouliRoudsari M, Hosseini Hashemi B. Experimental evaluation of rigid connection with reduced section and replaceable fuse. Structures, 2018;16:390404. https://doi.org/10.1016/i.istruc.2018.11.010

[9] Mahmoudi F, Dolatshahi KM, Mahsuli M, Nikoukalam MT, Shahmohammadi A. Experimental study of steel moment resisting frames with shear link. Journal of Constructional Steel Research, 2019;154:197-208. https://doi.org/10.1016/i.jcsr.2018.11.027

[10] Özkılıç YO. Experimental and numerical studies on replaceable links for eccentrically braced frames. Ph. D. Dissertation, Middle East Technical University, 2020. https://doi.org/10.1016/i.engstruct.2021.112225

[11] Özkılıç YO. Optimized stiffener detailing for shear links in eccentrically braced frames. Steel and Composite Structures, 2021;39(1):35-50. http://dx.doi.org/10.12989/scs.2021.39.1.035

[12] Özkılıç YO, Bozkurt MB, Topkaya C. Mid-spliced end-plated replaceable links for eccentrically braced frames. Engineering Structures, 2021;237:112225. https://doi.org/10.1016/i.engstruct.2021.112225

[13] Özkılıç YO, Topkaya C. Extended End-Plate Connections for Replaceable Shear Links. Engineering Structures, 2021;240:112385. https://doi.org/10.1016/i.engstruct.2021.112385

[14] Ng YH, Shanmugam NE, Yu CH, Liew JYR. Experimental Investigation of the Behaviour of End-Plate Connections. In Advances in Steel Structures: Proceedings of International Conference on Advances in Steel Structures, 11-14 December, 1996. https://doi.org/10.1016/B978-008042830-7/50055-3

[15] Yorgun C. Evaluation of innovative extended end-Plate moment connections under cyclic loading. Turkish Journal of Engineering and Environmental Sciences, 2002;26:48392.

[16] Abidelah A, Bouchaïr A, Kerdal DE. Experimental and analytical behavior of bolted end-plate connections with or without stiffeners. Journal of Constructional Steel Research, 2012;76:13-27. https://doi.org/10.1016/i.jcsr.2012.04.004

[17] Girão Coelho AM, Bijlaard FSK, Simões da Silva L. Experimental assessment of the ductility of extended end plate connections. Engineering Structures, 2004;26:1185-206. https://doi.org/10.1016/i.engstruct.2000.09.001

[18] Zhu C, Rasmussen Kim JR, Yan S, Zhang H. Experimental Full-Range Behavior Assessment of Bolted Moment End-Plate Connections. Journal of Structural Engineering, 2019;145:04019079. https://doi.org/10.1061/(ASCE)ST.1943-541X.0002368

[19] Özkılıç YO, Topkaya C. The plastic and the ultimate resistance of four-bolt extended end-plate connections. Journal of Constructional Steel Research, 2021;181:106614. https://doi.org/10.1016/i.jcsr.2021.106614

[20] Bezerra LM, Bonilla J, Silva WA, Matias WT. Experimental and numerical studies of bolted T-stub steel connection with different flange thicknesses connected to a rigid base. Engineering Structures,

2020;218:110770. https://doi.org/10.1016/j.engstruct.2020.110770

[21] Chen C, Zhang X, Zhao M, Lee C-K, Fung T-C, Chiew S-P. Effects of Welding on the Tensile Performance of High Strength Steel T-stub Joints. Structures, 2017;9:70-8. https://doi.org/10.1016/j.istruc.2016.09.008

[22] Girão Coelho AM, Bijlaard FSK, Gresnigt N, Simões da Silva L. Experimental assessment of the behaviour of bolted T-stub connections made up of welded plates. Journal of Constructional Steel Research, 2004;60:269-311. https://doi.org/10.1016/j.jcsr.2003.08.008 
[23] Guo H, Liang G, Li Y, Liu Y. Q690 high strength steel T-stub tensile behavior: Experimental research and theoretical analysis. Journal of Constructional Steel Research, 2017;139:473-83. https://doi.org/10.1016/j.jcsr.2017.10.007

[24] Liang G, Guo H, Liu Y, Li Y. Q690 high strength steel T-stub tensile behavior: Experimental and numerical analysis. Thin-Walled Structures, 2018;122:554-71. https://doi.org/10.1016/j.tws.2017.10.042

[25] Zhu X, Wang P, Liu M, Tuoya W, Hu S. Behaviors of one-side bolted T-stub through thread holes under tension strengthened with backing plate. Journal of Constructional Steel Research, 2017;134:53-65. https://doi.org/10.1016/j.jcsr.2017.03.010

[26] EN 1998-1: Design of structures for earthquake resistance-Part 1: General rules, seismic actions and rules for buildings. 2004.

[27] Bouchaïr A, Averseng J, Abidelah A. Analysis of the behaviour of stainless steel bolted connections. Journal of Constructional Steel Research, 2008;64:1264-74. https://doi.org/10.1016/j.jcsr.2008.07.009

[28] Massimo L, Gianvittorio R, Aldina S, da Silva Luis S. Experimental analysis and mechanical modeling of T-stubs with four bolts per row. Journal of Constructional Steel Research, 2014;101:158-74. https://doi.org/10.1016/j.jcsr.2014.05.004

[29] Brown D, Iles D, Brettle M, Malik A, Group BSC. Joints in Steel Construction: MomentResisting Joints to Eurocode 3. 2013.

[30] Yun X, Gardner L. Stress-strain curves for hot-rolled steels. Journal of Constructional Steel Research, 2017;133:36-46. https://doi.org/10.1016/j.jcsr.2017.01.024

[31] Qiang X, Wu N, Luo Y, Jiang X, Bijlaard F. Experimental and Theoretical Study on High Strength Steel Extended Endplate Connections After Fire. International Journal of Steel Structures,2018;18:609-34. https://doi.org/10.1007/s13296-018-0020-3

[32] Faralli AC. Large deformation of T-stub connection in bolted steel joints. Ph. D. Dissertation, University College London, 2019.

[33] Özkılıç YO. A Comparative Study on Yield Line Mechanisms for Four Bolted Extended End-Plated Connection. Challenge Journal of Structural Mechanics, 2021;7(2). 